\title{
Low Prevalence of Hepatitis C Virus Infection Among HIV-Positive Patients: Data From a Large-Scale Cohort Study in Istanbul, Turkey
}

\author{
Ozlem Altuntas Aydin ${ }^{1,}$; Mucahit Yemisen ${ }^{2}$; Hayat Kumbasar Karaosmanoglu ${ }^{1}$; Fatma \\ Sargin $^{3}$; Alper Gunduz ${ }^{4}$; Bahadir Ceylan ${ }^{5}$; Bilgul Mete ${ }^{2}$; Nail Ozgunes ${ }^{3}$; Dilek Yildiz Sevgi ${ }^{4}$; \\ Resat Ozaras ${ }^{2}$; Fehmi Tabak ${ }^{2}$ \\ ${ }_{2}^{1}$ Department of Infectious Diseases and Clinical Microbiology, Haseki Training and Research Hospital, Istanbul, Turkey \\ ${ }_{3}^{2}$ Department of Infectious Diseases and Clinical Microbiology, Cerrahpasa Medical Faculty, Istanbul University, Istanbul, Turkey \\ ${ }^{3}$ Department of Infectious Diseases and Clinical Microbiology, Goztepe Training and Research Hospital, Istanbul Medeniyet University, Istanbul, Turkey \\ ${ }_{5}^{4}$ Department of Infectious Diseases and Clinical Microbiology, Sisli Etfal Training and Research Hospital, Istanbul, Turkey \\ 5 Department of Infectious Diseases and Clinical Microbiology, Medical Faculty, Bezmialem Vakif University, Istanbul, Turkey \\ ${ }^{*}$ Corresponding Author: Ozlem Altuntas Aydin, Department of Infectious Diseasaes and Clinical Microbiology, Haseki Training and Research Hospital, Aksaray-Fatih, Istanbul, Turkey. \\ Tel:+90-2125294400, Fax:+90-5057962570, E-mail: ozlemaa@gmail.com
}

Received: February 9, 2014; Revised: April 29, 2014; Accepted: August 7, 2014

\begin{abstract}
Background: Rate of coinfection with human immunodeficiency virus (HIV) and hepatitis C virus (HCV) varies in different countries. This may be attributable to common transmission routes as well as social, economic and cultural factors.

Objectives: The purpose of this study was to investigate the prevalence and risk factors of HCV infection among HIV-positive patients in Istanbul, Turkey.

Patients and Methods: Since January 2006 to November 2013, 949 HIV-positive patients that were enrolled in this study by ACTHIV-IST (Action Against HIV in Istanbul) Study Group, which consists of five centers to follow up HIV-positive patients in Istanbul. Epidemiologic and clinical data were collected retrospectively from medical records and were transferred to an HIV database system.

Results: Among 949 patients, 84\%were men and the mean age was $37.92 \pm 11.54$ years (range,17-79). The most frequent route of transmission was heterosexual intercourse (48.8\%), followed by men having sex with men (30.5\%). Only nine patients (0.9\%) had history of injection drug use (IDU). The prevalence of HIV/HCV coinfection was 0.9\% (9:949). The IDU rate was 44.4\% (4:9) in patients with HIV/HCV coinfection (three of them were not Turkish citizens), whereas this rate was only $0.6 \%(5: 881)$ in patients with only HIV infection ( $\mathrm{P}<0.01)$. Genotypes $1 \mathrm{~b}, 2 \mathrm{a} / 2 \mathrm{c}$, and 3 were determined in five, one, and two patients, respectively. Genotype could not be determined in one patient. History of residence in a foreign country $(\mathrm{P}<0.01)$ and imprisonment $(\mathrm{P}<0.01)$ were also considered as risk factors in terms of HIV/HCV coinfection.

Conclusions: Prevalence of HIV/HCV coinfection is considerably low in Turkey. The extremely rare prevalence of IDU might have a role in this low prevalence.
\end{abstract}

Keywords: Human Immunodeficiency Virus; Hepatitis C Virus; Prevalence; Turkey

\section{Background}

Coinfection with immunodeficiency virus (HIV) and hepatitis C virus (HCV) is commonly observed due to their common routes of transmission. Moreover, almost one-quarter of patients with HIV/AIDS are also infected with HCV (1). In areas where highly active antiretroviral therapy (HAART) is available, HCV infection has become a major cause of mortality among HIV-positive patients and hence, the life expectancy has decreased (2). Patients with HIV/HCV coinfection are more likely to develop cirrhosis and have an increased risk of developing AIDS (3). For these reasons, American and European guidelines recommend HCV screening of all HIV-positive individuals (4-6).

The rate of HIV/HCV coinfection differs from country to country. This may be attributable to their common transmission routes and social, economic, and cultural factors.
For HIV and HCV, the most common transmission routs are exposure to blood and injections drug use (IDU). In the developed countries such as the United States, Australia, and many European countries, IDU is the dominant route of HCV transmission. However, the transmission is attributed to unsafe therapeutic injections for HCV infection in Egypt (with the highest reported HCV seroprevalence worldwide) and in India (7). The main route of HIV transmission differs by region. For instance, the main route is heterosexual intercourse in sub-Saharan Africa and homosexual intercourse in North America and Latin America. Nevertheless, IDU is the most common route of HIV transmission in Eastern Europe and Central Asia. Although heterosexual transmission accounts for the largest proportion of HIV transmission in Western Europe, the incidence has increased in men who have sex with men (MSM) during recent years (8). It has been re-

Copyright ( ) 2014, Kowsar Corp.; Published by Kowsar Corp. This is an open-access article distributed under the terms of the Creative Commons Attribution License, which permits unrestricted use, distribution, and reproduction in any medium, provided the original work is properly cited. 
ported that in Middle Eastern countries such as Iran, IDU is the most common high-risk behavior for HIV and HCV transmission (9). The risk of vertical transmission is high for HIV and relatively low for HCV, but the risk increases for HIV-positive mothers (10). Although rate of HCV transmission by sexual route is low, incremental trend of detecting HCV among HIV-positive MSM has been reported from many countries recently $(11,12)$.

Turkey is among low-prevalence countries in Europe in terms of both HIV and HCV infections. Despite common transmission routes, data on HCV seroprevalence among patients with HIV/AIDS in our country is insufficient.

\section{Objectives}

The aim of this study was to determine the prevalence and associated risk factors of HCV infection among HIVpositive patients who were followed up by five centers in Istanbul, a large cosmopolitan city in Western Turkey.

\section{Patients and Methods}

The HIV-positive patients were enrolled in this retrospective study by ACTHIV-IST (Action against HIV in Istanbul) Study Group, which consists of five centers to follow up HIV-positive patients in Istanbul. Three of these centers are located in university hospitals and two are in public training hospitals. All newly diagnosed HIV/AIDS patients with confirmed diagnosis through Western Blot verification test (HIV BLOT 2.2, MP Biomedicals Asia Pacific, Singapore) who attended the abovementioned clinics between January 2006 and November 2013 were included. None of the patients with HIV/HCV coinfection had received treatment for $\mathrm{HCV}$. The patients were screened for HCV antibodies by ELISA method (Inno-test HCV Ab IV, Innogenetics, Belgium) and HCV-RNA levels of seropositive patients were detected by polymerase chain reaction (PCR) (COBAS Ampliprep/COBAS TaqMan 96, Roche Molecular Systems, USA). Sera with detected HCV RNA were genotyped (Abbott RealTime HCV Genotype II, IL). The CD4+ cell counts were obtained by standard flow cytometry (FACScalibur, Becton Dickinson, New Jersey, USA) and HIV viral load was measured by PCR (COBAS Ampliprep/COBAS TaqMan HIV-1 Test, Roche Molecular Systems, USA). Demographic data including age, sex, transmission routes, education level, marital status, and history of imprisonment, CD4+ counts, HIV RNA, Anti-HCV, and HCV RNA were collected retrospectively from medical records and were transferred to a HIV database system.

All analysis were performed by using GraphPad Prism 5.0 (GraphPad Software, Inc., San Diego, CA, USA) and SPSS 15 (SPSS Inc, Chicago, IL, USA). Data were described using mean \pm standard deviation (SD) (or median and range) and as an absolute number and percentage when indicated. The student $t$ test was used to analyze quantitative data. A P value $<0.05$ was considered as statistically significant.

\section{Results}

A total of 949 naive HIV-positive patients were enrolled in this study. Among the included patients, 797 (84\%) were male and the mean age was $37.92 \pm 11.54$ years (range, $17-$ 79). Moreover, 21 patients (2.2\%) were not Turkish citizens. Most frequent route of HIV transmission was heterosexual intercourse (48.8\%) and MSM (30.5\%), consecutively.

\begin{tabular}{|c|c|c|c|}
\hline & $\begin{array}{l}\text { Patients With HIV/HCV Coin- } \\
\text { fected, }(n=9), \text { No. }(\%)\end{array}$ & $\begin{array}{l}\text { HIV-Positive Patients, }(\mathbf{n}= \\
\text { 940), No. }(\%)\end{array}$ & P value \\
\hline Mean Age, $y$ & 34 & 38 & 0.42 \\
\hline HIV Transmission Route & & & $<0.01$ \\
\hline Heterosexual & $5(55.5)$ & $466(49.6)$ & \\
\hline Homosexual & 0 & $289(30.7)$ & \\
\hline Intravenous Drug Use & $4(44.5)$ & $5(0.5)$ & \\
\hline Level of Education, $(N=621)$ & & & 0.94 \\
\hline Illiterate & 0 & 15 & \\
\hline Elementary-Secondary & 3 & 231 & \\
\hline Highschool & 3 & 158 & \\
\hline University & 3 & 227 & \\
\hline $\begin{array}{l}\text { Residence in a Foreign } \\
\text { Country }\end{array}$ & & & $<0.01$ \\
\hline Yes & $6(66.6)$ & $132(14)$ & \\
\hline No & $3(33.4)$ & $808(86)$ & \\
\hline History of Imprisonment & & & $<0.01$ \\
\hline Yes & $1(11.1)$ & $10(1.1)$ & \\
\hline No & $8(88.9)$ & 930 (98.9) & \\
\hline
\end{tabular}


Only nine patients $(0.9 \%)$ had history of injection drug use (IDU). The CD4+ lymphocyte count and HIV RNA had been performed on 895 of the cases. Mean CD4+ lymphocyte count at the first admission was $364.24 \pm 280.83 / \mathrm{mm}^{3}$ (range, 0-2106) and mean plasma HIV RNA was $4.97 \pm 0.97$ log10 copies $/ \mathrm{mL}$. The CD4+ lymphocyte count $<200 / \mathrm{mm}^{3}$ and $>500 / \mathrm{mm}^{3}$ were reported in $223(24.9 \%)$ and $220 \mathrm{pa-}$ tients (24.6\%), respectively.

The number of HIV-positive individuals with positive titers for anti-HCV antibodies was 9 (0.9\%), consisting of five females and four males, with detection of HCV RNA in all of them. The hepatitis B virus surface antigen (HBsAg) was detected in 59 patients. Nevertheless, the HCV/HBV| HIV coinfection was not identified in any patients. Table 1 shows the demographic characteristics of the patients according to HCV seropositivity (Table 1). In patients with HIV/HCV coinfection, the IDU as the route of HIV transmission, residence in a foreign country, and history of imprisonment had a significant association with HIV/ $\mathrm{HCV}$ coinfection.

All of the patients with HIV/HCV coinfection were Caucasian. Three of them were not Turkish citizens (two from Moldova and one from Turkmenistan).

Genotype analysis revealed the genotype $1 \mathrm{~b}, 2 \mathrm{a} / 2 \mathrm{c}$, and 3 in five, one, and two patients, respectively. Genotype could not be determined in one patient.

The mean CD4+ counts for patients with HIV/HCV coinfection and HIV-positive patients were $128 \pm 139$ and $336 \pm$ 226 cells $/ \mathrm{mm}^{3}$, respectively $(\mathrm{P}=0.06)$. No significant difference was detected in terms of HIV-RNA level between two groups $(\mathrm{P}=0.924)$.

\section{Discussion}

This study indicated that the prevalence of HIV/HCV coinfection in our country is considerably low (0.9\%). Although occult HCV infection is a concern in HIV-positive patients, HCV-RNA testing is recommended in case of unexplained transaminase elevation in those with a CD4+< $200 / \mathrm{mm}^{3}$, when acute HCV is suspected, or among subjects with a high risk of acquiring HCV (13). In our study, 223 patients with HIV/HCV coinfection had CD4+<200/ $\mathrm{mm}^{3}$ and none had high ALT or suspicion of acute HCV infection. Therefore, we did not test HCV RNA in this group.

Depending on the mode of HIV transmission, the prevalence of $\mathrm{HIV} / \mathrm{HCV}$ coinfection varies from one country to another (14). As the main route of HCV spread is IDU, HIV/ HCV coinfection rates are often more than $90 \%$ among patients with HIV/AIDS who are injection drug users. High $\mathrm{HIV} / \mathrm{HCV}$ coinfection rates (around 70\%) can be found in Eastern European countries (e.g. Belarus and Ukraine) and in Middle Eastern countries such as Iran where IDU is the main route of HIV transmission (15-17). Nevertheless, in Western Europe, for example in Barcelona, the prevalence of HCV coinfection among newly diagnosed HIVpositive patients had decreased from $24 \%$ between 2000 2002 to $10 \%$ in the years $2006-2008$ as a result of needle exchange programs among injection drug users (18). On the contrary, HCV coinfection among HIV-positive patients was as low as $3.39 \%$ in Northeast Brazil, which was associated with low IDU rate in HIV-positive patients (19). In Turkey, the first case of HIV/AIDS was reported in 1985. According to the survey conducted by the Turkish Ministry of Health, there were 6854 cases of HIV infection out of a population of 76.6 million people in Turkey between October 1985 and June 2013. In a recent study on the antiretroviral-naive Turkish patients with HIV-1, the transmission route was reported as sexual intercourse (heterosexual contact in $60 \%$ and homosexual contact in $38 \%)$ and IDU in just $2 \%(20,21)$. According to a study covering the whole country (TURKHEP Study), the HCV seroprevalence rate was $1 \%$ in Turkey (22). Moreover, referring to a conducted meta-analysis in our country, while the HCV seroprevalence rate was $0.1 \%$ to $0.8 \%$ according to the geographic areas, the rates among blood donors, preoperative patients, sex workers, and hemodialysis patients were $0.3 \%, 0.6 \%$ to $1.3 \%, 2.2 \%$, and $20.4 \%$, respectively (23). In another study by Karaca et al., the most common risk factors of HCV infection were history of surgery (98\%), blood transfusion (39.7\%), and dental procedure (27.5\%). In addition, history of IDU (3.1\%) and suspicious sexual intercourse (1.5\%) were determined as minor risk factors (24).

According to the aforementioned studies, heterosexual intercourse is the most frequenr route of HIV transmission in Turkey. Moreover, IDU is the least common risk factor in the transmission of both HIV and HCV. According to a study conducted in Turkey, the IDU prevalence rate had been $0.05 \%$ in general population (25). In our study, only 9 patients (0.9\%) had the history of IDU among all the cases while the rate was $44.4 \%$ (4:9) in patients with $\mathrm{HIV} / \mathrm{HCV}$ coinfection; however, three were not Turkish citizens and the other three had resided out of Turkey. In addition to IDU, a history of residence in a foreign country was determined as a risk factor in terms of HIV/HCV coinfection in our patients.

Although rate of sexual transmission of HCV is known to be low in serodiscordant heterosexual couples, there has been a dramatic rise in the incidence of HCV among HIVinfected MSM in Europe, the United States, Australia, and Asia since 2000 (26-29). Increases in HCV seroconversion among HIV-positive MSM have been reported in association with unprotected anal intercourse, multiple sexual partners, rough sexual techniques, and coinfection with HIV and other sexually transmitted infections $(2,14)$. In our study on the contrary, none of the coinfected patients had reported homosexual intercourse.

Previous studies have revealed at least six major genotypes and more than 70 subtypes of HCV (30). HCV genotypes 1, 2, and 3 have a worldwide distribution, genotype 4 is prevalent in Africa and Middle East, genotype 5 and 6 are found in South Africa and Southeast Asia, respectively (31). According to a multicenter study in Turkey during 2009, HCV genotype 1 was the predominant one (87.5\%) in 834 patients (32). Similarly, HCV genotype $1 \mathrm{~b}$ was also 
predominant in our study (5:8, 62.5\%). Nevertheless, two patients with genotype 3 had been infected in Germany and in China through IDU. The only patient with genotype 2a/2c was infected through IDU in Moldova.

The possible limitation of this study might be due to the low number of the patients with HIV/HCV coinfection; however, it was unavoidable since the total number of patients with HIV/AIDS coinfection is low in Turkey.

In conclusion, the prevalence rate of HCV among HIVpositive patients in our study was similar to the rate in Turkey. Furthermore, the prevalence level detected in our patients with HIV/HCV coinfection was the lowest ever reported rate in the literature. The extremely rare prevalence of HCV infection among HIV-positive population in our country might be a consequence of the small number of the injection drug users. Additionally, relatively low rate of MSM among our HIV-positive patients might have a role in low HIV/HCV coinfection prevalence. Although the prevalence of HCV coinfection is low among HIV-positive patients, HCV should also be screened in all patients with HIV/AIDS.

\section{Authors' Contributions}

Study concept and design: Ozlem Altuntas Aydin and Fehmi Tabak; acquisition of data: Ozlem Altuntas Aydin and MucahitYemisen; analysis and interpretation of data: Ozlem Altuntas Aydin, Bilgul Mete, Mucahit Yemisen, and Alper Gunduz; drafting of the manuscript: Ozlem Altuntas Aydin, Hayat Kumbasar Karaosmanoglu, Bilgul Mete, and Fehmi Tabak; critical revision of the manuscript for important intellectual content: Resat Ozaras, Hayat Kumbasar Karaosmanoglu, Fehmi Tabak, Bilgul Mete, Alper Gunduz, Dilek Yildiz Sevgi, Fatma Sargin, and Mucahit Yemisen; statistical analysis: Mucahit Yemisen; administrative, technical, and material support: Fehmi Tabak, Nail Ozgunes, and Bahadir Ceylan; and study supervision: Ozlem Altuntas Aydin and Fehmi Tabak.

\section{References}

1. Soriano V, Vispo E, Labarga P, Medrano J, Barreiro P. Viral hepatitis and HIV co-infection. Antiviral Res. 2010;85(1):303-15.

2. Naggie S, Sulkowski MS. Management of patients coinfected with HCV and HIV: a close look at the role for direct-acting antivirals. Gastroenterology. 2012;142(6):1324-1334 e3.

3. Andreoni M, Giacometti A, Maida I, Meraviglia P, Ripamont D, Sarmati L. HIV-HCV co-infection: epidemiology, pathogenesis and therapeutic implications. Eur Rev Med Pharmacol Sci. 2012;16(11):1473-83.

4. Guidelines.: EACS European ADS Clinical Society; 2012.

5. Wilkins E, Nelson M, Agarwal K, Awoyemi D, Barnes E, Bhagani $S$, et al. British HIV Association guidelines for the management of hepatitis viruses in adults infected with HIV 2013. HIV Med. 2013;14(S4):1-71.

6. Aberg JA, Gallant JE, Ghanem KG, Emmanuel P, Zingman BS, Horberg MA. Primary care guidelines for the management of persons infected with HIV: 2013 update by the HIV medicine association of the infectious diseases society of America. Clinical Infect Dis. 2013:cit665.

7. Shepard CW, Finelli L, Alter MJ. Global epidemiology of hepatitis C virus infection. Lancet Infect Dis. 2005;5(9):558-67.
8. Kilmarx PH. Global epidemiology of HIV. Curr Opin HIV AIDS. 2009;4(4):240-6.

9. Keramat F, Eini P, Majzoobi MM. Seroprevalence of HIV, HBV and HCV in Persons Referred to Hamadan Behavioral Counseling Center, West of Iran. Iran Red Crescent Med J. 2011;13(1):42-6.

10. Larsen C, Pialoux G, Salmon D, Antona D, Le Strat Y, Piroth L, et al Prevalence of hepatitis C and hepatitis B infection in the HIV-infected population of France, 2004. Euro Surveill. 2008;13(22):71727.

11. Browne R, Asboe D, Gilleece Y, Atkins M, Mandalia S, Gazzard B, et al. Increased numbers of acute hepatitis $\mathrm{C}$ infections in HIV positive homosexual men; is sexual transmission feeding the in crease? Sex Transm Infect. 2004;80(4):326-7.

12. van de Laar TJ, van der Bij AK, Prins M, Bruisten SM, Brinkman K Ruys TA, et al. Increase in HCV incidence among men who have sex with men in Amsterdam most likely caused by sexual transmission. J Infect Dis. 2007;196(2):230-8.

13. Matthews GV, Dore GJ. HIV and hepatitis C coinfection. J Gastroenterol Hepatol. 2008;23(7 Pt1):1000-8.

14. Taylor LE, Swan T, Mayer KH. HIV coinfection with hepatitis C virus: evolving epidemiology and treatment paradigms. Clin Infect Dis. 2012;55 Suppl 1:S33-42.

15. Ataei B, Tayeri K, Kassaian N, Farajzadegan Z, Babak A. Hepatitis B and $\mathrm{C}$ among patients infected with human immunodeficiency virus in Isfahan, Iran: seroprevalence and associated factors. Hepat Mon. 2010;10(3):188-92.

16. SeyedAlinaghi S, Jam S, Mehrkhani F, Fattahi F, Sabzvari D, Kourorian Z, et al. Hepatitis-C and hepatitis-B co-infections in patients with human immunodeficiency virus in Tehran, Iran. Acta Med Iran. 2011;49(4):252-7.

17. Olinger CM, Lazouskaya NV, Eremin VF, Muller CP. Multiple genotypes and subtypes of hepatitis B and C viruses in Belarus: similarities with Russia and western European influences. Clin Microbiol Infect. 2008;14(6):575-81.

18. Trevino A, Rivas P, Herrero-Mendoza M, Toro C, Soriano V, de Mendoza C, editors. Newly Diagnosed HIV-1 Individuals in Spain since Year 2000. Non-B Subtypes, and Hepatitis C and B Virus Coinfections. .; 16th Conference on Retroviruses and Opportunistic Infections.; 2009; Montreal, Canada. Montreal, Canada: 2009. p. p. 300 .

19. Oliveira-Filho AB, Oliveira EH, Castro JA, Silva LV, Vallinoto AC, Lemos JA. Epidemiological aspects of HCV infection in HIV infected individuals in Piaui State, Northeast Brazil. Arch Virol. 2012;157(12):2411-6

20. HATAM.. HIV / AIDS cases according to the year of Distribution. Ankara: T. C. Ministry of Health; 2013. Available from: http://www. hatam.hacettepe.edu.tr/verilerAralik2012.pdf.

21. Karaosmanoglu HK, Aydin OA, Nazlican O. Profile of HIV/AIDS patients in a tertiary hospital in Istanbul, Turkey. HIV Clin Trials. 2011;12(2):104-8.

22. Tozun N, Ozdogan OC, Cakaloglu Y, Idilman R, Karasu Z, Aakarca US, et al. Nationwide prevalence study and risk factors for hepatitis A, B, C and D infections in Turkey. Hepatology. 2010;52(Suppl 1):697A.

23. Mistık, R.. Hepatit C virus infection epidemiology. In: Tabak, F., Tosun, S. editors. Viral Hepatit 2013.. Istanbul: Istanbul Tip Kitabevi; 2013. pp. 83-113.

24. Karaca C, Cakaloglu Y, Demir K, Ozdil S, Kaymakoglu S, Badur S, et al. Risk factors for the transmission of hepatitis $C$ virus infection in the Turkish population. Dig Dis Sci. 2006;51(2):365-9.

25. Ministry of Interior General Directorate of Security.. TC drug report Ministry of Interior General Directorate of Security Department of Anti-Smuggling and Organized Crime. Ankara; 2013.

26. Danta M, Brown D, Bhagani S, Pybus OG, Sabin CA, Nelson M, et al Recent epidemic of acute hepatitis $\mathrm{C}$ virus in HIV-positive men who have sex with men linked to high-risk sexual behaviours. AIDS. 2007;21(8):983-91.

27. Fierer DS, Factor SH, Uriel AJ, Carriero DC, Klepper A, Dietrich DT. Sexual transmission of hepatitis C virus among HIV-infected men who have sex with men--New York City, 2005-2010. MMWR 2011;60(28):945. 


\section{Altuntas Aydin $O$ et al.}

28. Gamage DG, Read TR, Bradshaw CS, Hocking IS, Howley K, Chen MY, et al. Incidence of hepatitis-C among HIV infected men who have sex with men (MSM) attending a sexual health service: a cohort study. BMC Infect Dis. 2011;11:39.

29. Urbanus AT, van de Laar TJ, Stolte IG, Schinkel J, Heijman T, Coutinho RA, et al. Hepatitis $C$ virus infections among HIV-infected men who have sex with men: an expanding epidemic. AIDS. 2009;23(12):F1-7.

30. Simmonds P, Bukh J, Combet C, Deleage G, Enomoto N, Feinstone
S, et al. Consensus proposals for a unified system of nomenclature of hepatitis C virus genotypes. Hepatology. 2005;42(4):96273.

31. Sy T, Jamal MM. Epidemiology of hepatitis $\mathrm{C}$ virus (HCV) infection. Int J Med Sci. 2006;3(2):41-6.

32. Tahan V, Ozaras R, Karaca C, Uraz S, Eren F, Danalioglu A, et al. Is HCV genotyping cost-effective even when the prevalences of genotypes 2 and 3 are low? Hepatogastroenterology. 2009;56(9495):1425-8. 